\title{
Optimization of Bacterial Cellulose Production from Wastewater of Noodle Processing by Komagataeibacter sp. PAP1 and Bio-Cellulose Paper Production
}

\author{
Tanyarat SUTTHIPHATKUL ${ }^{1}$, Amornrat SUWANPOSRI ${ }^{2}$ and \\ Duangjai OCHAIKUL ${ }^{1, *}$
}

\author{
${ }^{I}$ Department of Biology, Faculty of Science, King Mongkut's Institute of Technology Ladkrabang, \\ Bangkok 10520, Thailand \\ ${ }^{2}$ Department of Applied Science and Biotechnology, Faculty of Agro-Industrial Technology, Rajamangala \\ University of Technology Tawan-ok Chanthaburi Campus, Chanthaburi 22210, Thailand
}

('Corresponding author's e-mail: daungjai.oc@kmitl.ac.th)

Received: 5 March 2019, Revised: 20 January 2020, Accepted: 15 February 2020

\begin{abstract}
Bacterial Cellulose (BC) production from Fermented Rice Noodle Wastewater (FRNW) was fermented by Komagataeibacter sp. PAP1. In order to increase the production of BC, the FRNW-based medium was prepared and optimized for the cultivation of this bacterium. The optimized FRNW-based medium was composed of $5 \%(\mathrm{w} / \mathrm{v})$ mannitol, $0.1 \%(\mathrm{w} / \mathrm{v})$ beef extract, $0.5 \%(\mathrm{v} / \mathrm{v})$ ethanol, $1 \%(\mathrm{v} / \mathrm{v})$ acetic acid, $\mathrm{pH} 7.0$ which were incubated at $30{ }^{\circ} \mathrm{C}$ for 10 days. Under these conditions, BC yielded 11.76 $\pm 0.34 \mathrm{~g} / \mathrm{L}$ higher (4.40 fold) than the standard Hestrin-Schramm (HS) medium. The study on growth and $\mathrm{BC}$ production by Komagataeibacter sp. PAP1 in optimized culture condition showed that BC production by Komagataeibacter sp. PAP1 was growth-associated. The bacterial cell of Komagataeibacter sp. PAP1 increased exponentially from the $3^{\text {rd }}$ to $5^{\text {th }}$ day. The $\mathrm{BC}$ paper sheets produced using the obtained $\mathrm{BC}$ pellicle from an optimized FRNW-based medium gave higher mechanical strength than those from standard HS medium. This study reveals the use of FRNW as a substrate for BC production. The results indicated that FRNW, which is more environmentally friendly, can be used as an alternative low-cost substrate for BC production.
\end{abstract}

Keywords: Bacterial Cellulose, Fermented Rice Noodle Wastewater, Paper production, Komagataeibacter sp.

\section{Introduction}

Bacterial Cellulose or Bio-Cellulose (BC) is a bio-polysaccharide naturally produced by acetic acid bacteria in the genus of Komagataeibacter sp. [1]. Static cultivation methods have been widely used for the production of $\mathrm{BC}$, with pellicles of $\mathrm{BC}$ being formed on the surface of the static culture [2,3]. In recent years, $\mathrm{BC}$ has received great attention and has been applied in a variety of commercial applications due to its high tensile strength, high purity, and water holding capacity. BC has been used as a raw material for producing high-fidelity acoustic speakers, high-quality paper and dietary foods [4]. Moreover, $\mathrm{BC}$ has also been considered as an alternative source of cellulose because there are some properties of $\mathrm{BC}$ that are different from the traditional plant-derivers cellulose (PC). They are also advantageous for special application such as functionalized paper sheets, which are characterized by high strength, high filler load, wound dressing for severely damaged skin such as burns and chronic ulcers and electronic paper [5-7]. However, the production cost of $\mathrm{BC}$ is still high due to the use of quite an expensive culture media, and low BC yield. The factors affecting BC productivity are culture conditions such as medium components (carbon source, nitrogen source and supplementary substance), 
http://wjst.wu.ac.th

environmental factors (temperature, $\mathrm{pH}$ and dissolved oxygen) and cultivation methods [4]. A promising approach to reduce the production cost of $\mathrm{BC}$ is the optimization of culture conditions of celluloseproducing microorganism. An inexpensive industrial waste could be a reasonable substrate for the culture medium optimization.

Some industrial wastes including grape skins aqueous extract, sulfite pulping liquor, thin stillage, dry olive mill residue, waste beer yeast, and lipid fermentation wastewater have already been successfully used as the supplementary substance or growth medium for BC production [8-12]. Using industrial wastes as culture medium could not only provide a cheap method for producing BC, but it could also have an environmentally friendly effect by the removal of this waste from the environment.

Fermented Rice Noodle Wastewater (FRNW) which is decomposed easily and could result in environmentally harmful is produced in large volume by the boiling of fermented rice in noodle production. FRNW contains a high concentration of complex organic compounds, nutrient compounds and high $\mathrm{C} / \mathrm{N}$ ratio which could be utilized as substrate for microbial fermentation. FRNW has been used as a low-cost substrate for ethanol production by entrapped yeast cell [13]; however, FRNW has never been used as a growth medium for BC production.

In a previous study, cellulose producing bacteria were isolated from tropical fruits in Thailand and Komagataeibacter sp. PAP1 was considered as the most potential BC producer [14]. In this study, the BC from Komagataeibacter sp. PAP1 was produced by the use of FRNW as a low-cost substrate. Conditions for bacterial cultivation and cellulose production were optimized. In addition, BC paper was prepared from the produced BC under optimized conditions.

\section{Materials and methods}

\section{Preparation of inoculum}

Komagataeibacter sp. PAP1 was used as a BC producer. This bacterium was isolated from rotten papaya (Carica papaya). The bacteria produced the highest $\mathrm{BC}$ yield in the standard HS medium with the optimal growth at $25-30{ }^{\circ} \mathrm{C}$ and $\mathrm{pH} 4.5-7.0$ [14].

Komagataeibacter sp. PAP1 was cultivated on standard HS agar at $30{ }^{\circ} \mathrm{C}$ for $48 \mathrm{~h}$. Two loopfuls of the bacterium were transferred into a $500 \mathrm{~mL}$ Erlenmeyer flask containing $300 \mathrm{~mL}$ of sterilized starter medium. The starter medium consisted of $5 \%(\mathrm{w} / \mathrm{v})$ sucrose, $0.1 \%(\mathrm{w} / \mathrm{v})$ ammonium sulfate and $1.0 \%$ $(\mathrm{v} / \mathrm{v})$ acetic acid. The volume of the starter medium was adjusted to $300 \mathrm{~mL}$ using FRNW and the $\mathrm{pH}$ of the medium was adjusted to 6.0 using $0.1 \mathrm{~N} \mathrm{NaOH}$. The starter culture was carried out statically at $30^{\circ} \mathrm{C}$ for $72 \mathrm{~h}$.

\section{Preparation of Fermented Rice Noodle Wastewater (FRNW)}

FRNW was provided by a small noodle processing factory in Chachoengsao province. It was filtered with a filter cloth to separate the residues and kept at $-20{ }^{\circ} \mathrm{C}$.

\section{Production of BC using a FRNW based medium}

The $250 \mathrm{~mL}$ conical flask containing $100 \mathrm{~mL}$ of FRNW based medium was sterilized by using autoclave (ES 315, Tomy SEIKO Co., LTD, Japan). FRNW based medium consisted of $100 \mathrm{~mL}$ of FRNW, $5 \%$ sucrose, $0.1 \%$ ammonium sulfate, $1 \%$ acetic acid, $1 \%$ ethanol and the $\mathrm{pH}$ of the medium adjusted to 6.0 using $0.1 \mathrm{~N} \mathrm{NaOH}$. After that, $10 \mathrm{~mL}$ of the inoculums was transferred into the medium. The medium was incubated at $30^{\circ} \mathrm{C}$ for 7 days under static condition. BC pellicles formed were washed 3 times with distilled water, treated with $0.5 \mathrm{M} \mathrm{NaOH}$ at $80{ }^{\circ} \mathrm{C}$ for 30 min to eliminate residual bacterial cells and medium components. Purified cellulose pellicles were washed with distilled water and dried in a hot air oven (UNE 600, Memmert, Germany) at $65{ }^{\circ} \mathrm{C}$ until a constant weight was obtained. The BC production yield was presented as dry weight of BC per volume of culture medium $(\mathrm{g} / \mathrm{L})$.

\section{Optimization of cultivation conditions}

To obtain the maximum BC yield production by Komagataeibacter sp. PAP1, different physical and nutritional parameters were optimized using the "One Factor at a Time" (OFT) approach. The following 
parameters including $\mathrm{pH}$, carbon source, nitrogen source and ethanol concentration were optimized. All the optimization experiments were carried out in replications, and data were presented as the means of the replicates. The error bars indicated the standard deviation.

\section{Growth and BC production under optimal conditions}

The growth and BC production of Komagataeibacter sp. PAP1 were studied in $250 \mathrm{~mL}$ Erlenmeyer flasks under optimal conditions for 10 days. The viable bacterial cells were examined every day using the spread plate technique. The cell suspensions used for plating were obtained by vigorously shaking the culture flasks to release the bacterial cells from the cellulose pellicles [15]. Then, the flasks were serially diluted with $0.1 \%(\mathrm{w} / \mathrm{v})$ peptone, and $0.1 \mathrm{~mL}$ of each dilution was spread onto an agar plate containing an optimized FRNW based medium. The colonies were counted after 3 days of incubation.

Comparison of BC production in optimized FRNW-based medium and standard HS medium

Ten $\mathrm{ml}$ of the $72 \mathrm{~h}$ starter culture were transferred to the $250 \mathrm{~mL}$ Erlenmeyer flask containing 100 $\mathrm{mL}$ of optimized FRNW-based medium or standard HS medium $(2 \%(\mathrm{w} / \mathrm{v})$ glucose, $0.5 \%(\mathrm{w} / \mathrm{v})$ yeast extract, $0.5 \%(\mathrm{w} / \mathrm{v})$ peptone, $0.27 \%(\mathrm{w} / \mathrm{v})$ disodium hydrogen phosphate and $0.12 \%(\mathrm{w} / \mathrm{v})$ citric acid, $\mathrm{pH}$ of mixture 6.0). The culture was incubated statically for 10 days. After incubation, the yields of BC from each culture medium were analyzed.

Paper production using the produced BC in optimized FRNW-based medium and standard HS medium

The BC produced in both media was immersed in $0.5 \%$ ammonium hydroxide (v/v) overnight and washed 3 times with tap water. Subsequently, the BC pellicles were boiled for 30 min to remove ammonium hydroxide and washed 3 times with tap water. The BC pellicles were squeezed to remove the water on a pressing machine and then dried at $65^{\circ} \mathrm{C}$ for $3 \mathrm{~h}$.

\section{Paper analysis}

\section{Mechanical properties}

The dried BC pellicles were examined for tensile strength, Young's modulus and elongation at break using Thai Industrial Standard, TIS. 1353. 1997 with a Universal Testing Machine (UTM, model TA plus) at a test speed of $0.25 \mathrm{~mm} / \mathrm{min}$. For the measurement, rectangular specimens were cut from samples with a gauge length of the specimens of $30 \mathrm{~mm}$. Five specimens were performed to present the average results.

\section{Scanning electron microscope (SEM)}

For study a surface of $\mathrm{BC}$, the dried $\mathrm{BC}$ sample produced in both culture media was cut and coated with gold (Fine coater, model JEC-12000, JEOL Ltd., Japan) A JEOL scanning electron microscope (JSM 5410, JEOL Ltd., Japan) was used at $15 \mathrm{kV}$ for sample examination with 30,000 X magnifications.

\section{Results and discussion}

\section{Optimization of medium based on FRNW}

Fermented Rice Noddle Wastewater (FRNW) contained $11.11 \%$ of carbohydrate and $0.1 \%$ of protein that can be a nutrient source for microbial growth in bacterial cellulose production. In general, the medium composition and environmental factors affect bacterial cell growth and product formation [4]. Four main fermentation factors such as initial $\mathrm{pH}$ of culture medium, carbon sources, nitrogen sources and concentration of ethanol were chosen for the optimization of BC production by Komagataeibacter sp. PAP1 in FRNW-based medium. 
http://wjst.wu.ac.th

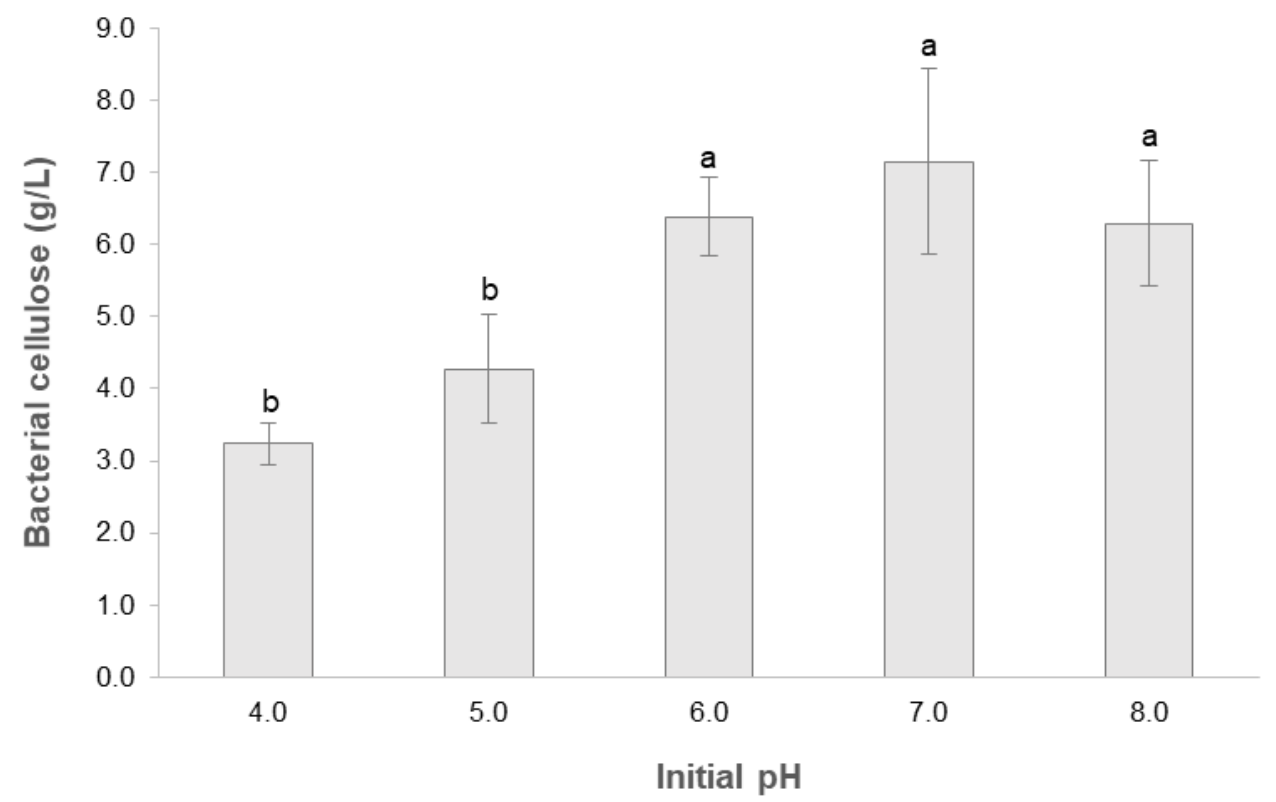

Figure 1 Effect of initial $\mathrm{pH}$ of the culture medium on BC production by Komagataeibacter sp. PAP1. Bars show the standard deviations of the mean values. Different lowercase letters above bars for each isolates indicate a significant difference at $p \leq 0.05$.

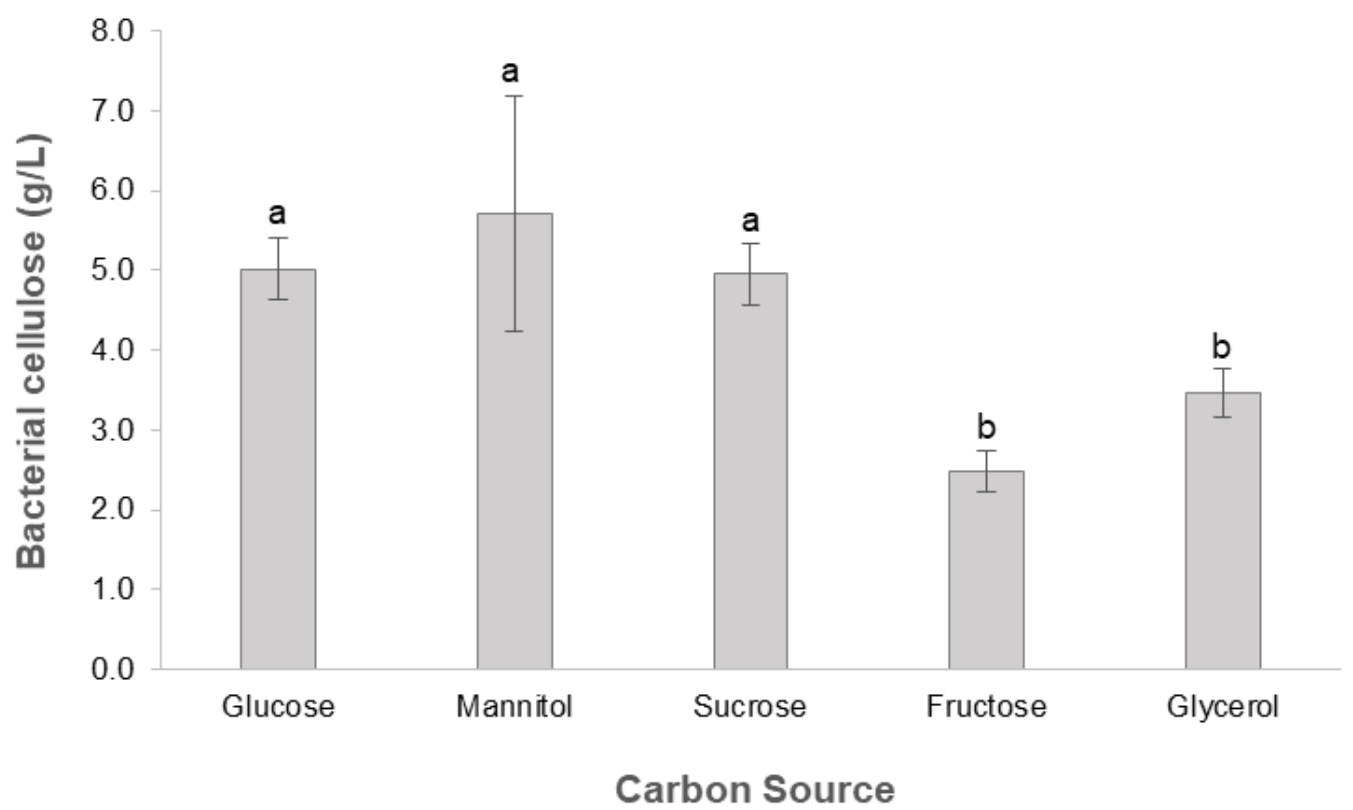

Figure 2 Effect of different carbon sources on BC production by Komagataeibacter sp. PAP1. Bars show the standard deviations of the mean values. Different lowercase letters above bars for each isolates indicate a significant difference at $p \leq 0.05$. 
http://wjst.wu.ac.th

\section{Effect of initial pH of medium on $\mathrm{BC}$ production}

The $\mathrm{BC}$ was produced in all $\mathrm{pH}$ evaluated and the maximum $\mathrm{BC}$ production of $7.15 \pm 1.28 \mathrm{~g} / \mathrm{L}$ was obtained at $\mathrm{pH}$ 7.0. Fontana et al. [16] indicated that the optimal $\mathrm{pH}$ range for BC production is $4.0-6.0$, while Jahan et al. [17] demonstrated $\mathrm{pH} 4.0-7.0$ as optimum $\mathrm{pH}$ range which is similar to as obtained in the present study. This is because the acetic acid bacteria grow well in this range [18]. The result showed in Figure 1.

\section{Effect of different carbon sources}

Various carbon sources at a final concentration of $5 \%(\mathrm{w} / \mathrm{v})$ were tested for their effects on BC production. As shown in Figure 2, mannitol was found to be the best carbon source with the maximum $\mathrm{BC}$ concentration of $5.71 \pm 1.48 \mathrm{~g} / \mathrm{L}$. Ramana et al. [19] reported that glucose, sucrose and mannitol were optimal carbon sources for BC synthesis. When mannitol was used as the sole carbon source, the maximum BC yield was obtained in the study of Nguyen et al. [20]. In many studies, other carbon sources such as fructose, sucrose, xylose, glycerol, arabitol and mannitol have proven to be better carbon source than glucose for BC production [21-22].

\section{Effect of different nitrogen sources}

Different nitrogen sources with concentration of $0.1 \%(w / v)$ were evaluated. As shown in Figure. 3, the cells of Komagataeibacter sp. PAP1 which was grown in the medium containing beef extract gave the highest amount of cellulose $(8.38 \pm 0.53 \mathrm{~g} / \mathrm{L})$. Hungund and Gupta [23] also reported that beef extract was the most suitable nitrogen source for BC production. Whereas, Son et al. [24] reported that the production of $4.16 \mathrm{~g} / \mathrm{L} \mathrm{BC}$ was achieved with the addition of $0.5 \%(\mathrm{w} / \mathrm{v})$ of yeast extract into the medium as a nitrogen source when Acetobacter sp. V6 was used. Nitrogen is the main component of protein in living organisms. It is necessary for cell growth and product formation [4]. The additional organic nitrogen source can stimulate cell growth and $\mathrm{BC}$ production.

\section{Effect of ethanol on BC production}

The effect of alcohol addition on BC production by Komagataeibacter sp. PAP1 was tested. The cellulose production was significantly enhanced from $1.66 \pm 0.36$ to $6.66 \pm 0.66 \mathrm{~g} / \mathrm{L}$ by the addition of $0.5 \%(\mathrm{v} / \mathrm{v})$ ethanol. Thus, it is clear that the addition of ethanol in the culture medium increased the BC yield. Ethanol acts as a stimulator for BC production as it is capable of generating the reduced form of $\mathrm{NADH}$ that lower the redox potential, which is necessary for optimal BC production [25]. At a higher ethanol concentration, BC production was declined because high concentration of ethanol could inhibit cell growth which result in decreasing BC production [17] (Figure 4).

\section{Studied on growth and BC production on optimized FRNW-based medium}

Based on the results obtained from OFT optimization, cell growth and BC production by Komagataeibacter sp. PAP1 were determined in the optimized FRNW-based medium containing $5.0 \%$ (w/v) mannitol, $0.1 \%(\mathrm{v} / \mathrm{v})$ beef extract, $0.5 \%(\mathrm{v} / \mathrm{v})$ ethanol, $\mathrm{pH} 7.0$. The cultures were grown at $30{ }^{\circ} \mathrm{C}$ under the static condition. As shown in Figure 5, bacterial cells of Komagataeibacter sp. PAP1 increased exponentially from the $3^{\text {rd }}$ to $5^{\text {th }}$ day. A stationary phase was observed after the $5^{\text {th }}$ day of cultivation.

$\mathrm{BC}$ production started after $24 \mathrm{~h}$ of cultivation and increased gradually with cultivation time, a maximum $\mathrm{BC}$ production of $11.76 \pm 0.34 \mathrm{~g} / \mathrm{L}$ was obtained on the $10^{\text {th }}$ day of cultivation. 
http://wjst.wu.ac.th

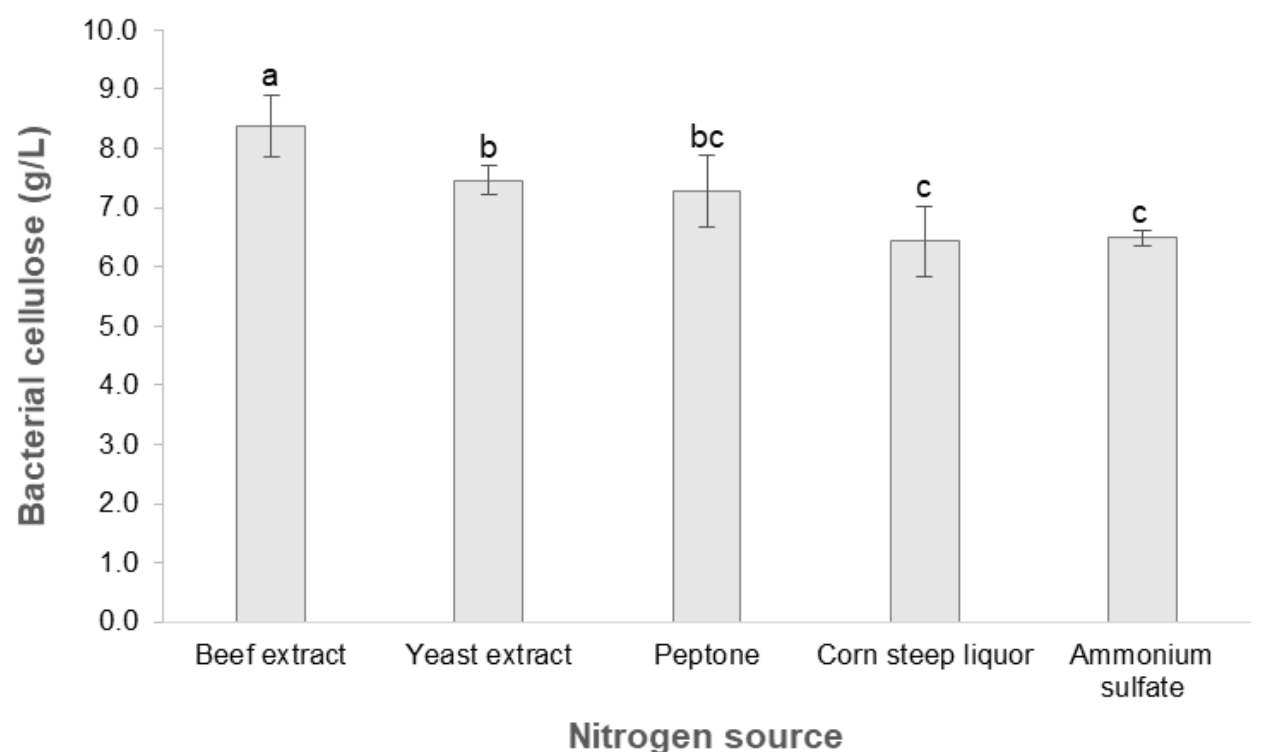

Figure 3 Effect of different nitrogen sources on BC production by Komagataeibacter sp. PAP1. Bars show the standard deviations of the mean values. Different lowercase letters above bars for each isolates indicate a significant difference at $p \leq 0.05$.

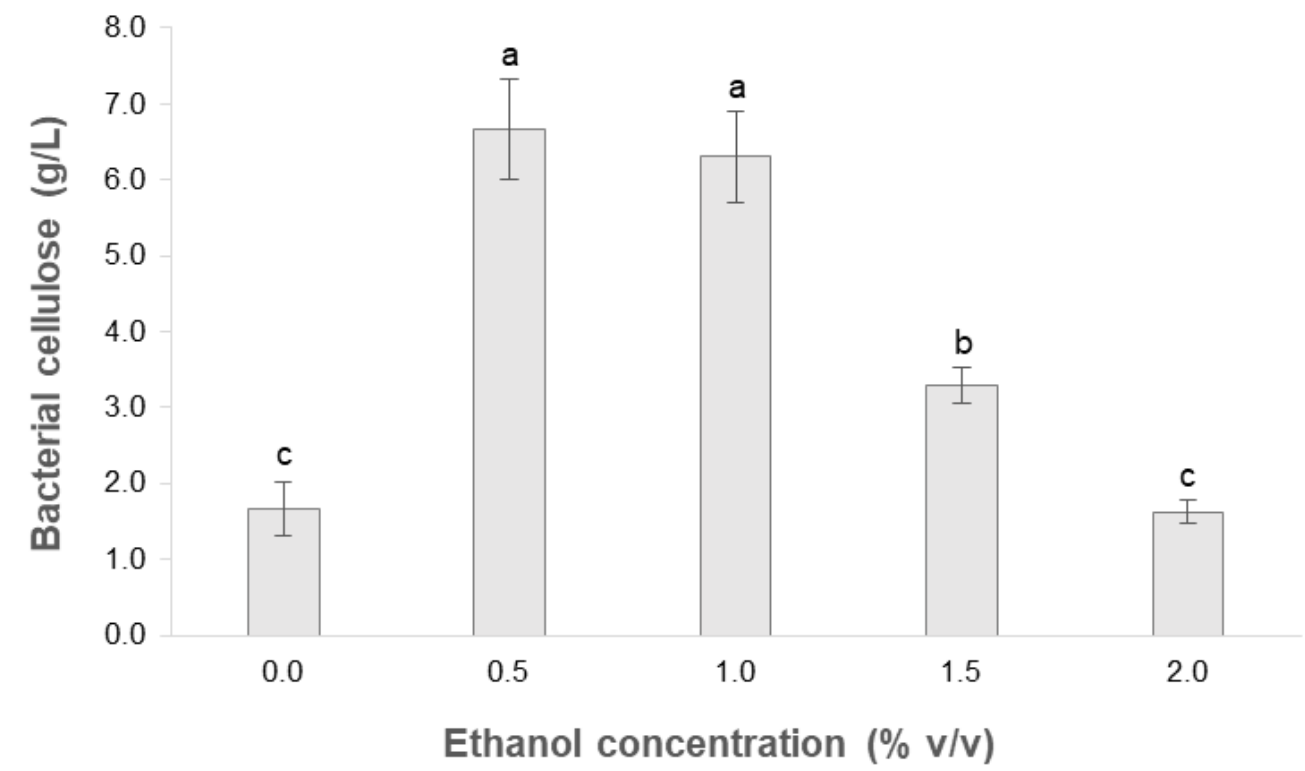

Figure 4 Effect of ethanol concentrations on BC production by Komagataeibacter sp. PAP1. Bars show the standard deviations of the mean values. Different lowercase letters above bars for each isolates indicate a significant difference at $p \leq 0.05$. 
http://wjst.wu.ac.th

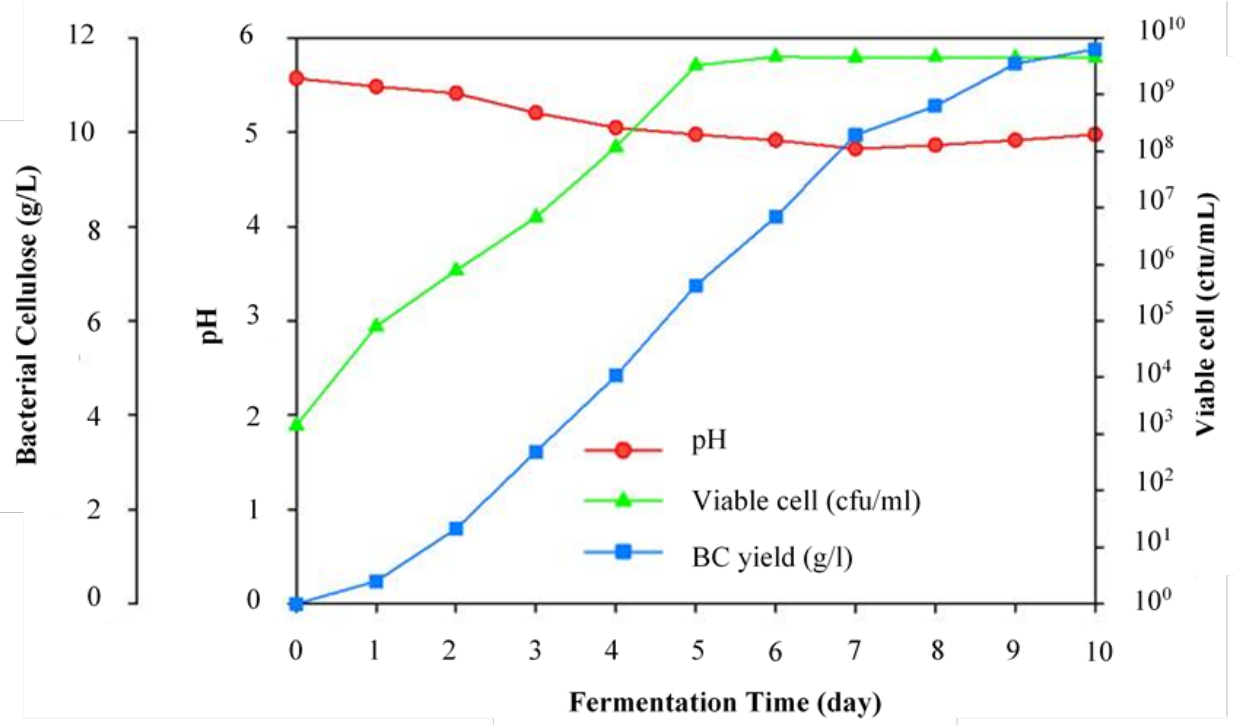

Figure 5 Growth and BC production of Komagataeibacter sp. PAP1 in optimized FRNW-based medium.

\section{Comparison of $\mathrm{BC}$ production}

The BC yields from the optimized FRNW-based medium was higher than the standard HS medium. The yield of BC obtained in the FRNW-based medium was $11.76 \pm 0.34 \mathrm{~g} / \mathrm{L}, 4.40$ times higher than that $(2.67 \pm 0.65 \mathrm{~g} / \mathrm{L})$ obtained in the latter medium, as shown in Table 1. The results suggested that FRNW has some accelerative properties which increase cell growth and BC production. The high productivity of $\mathrm{BC}$ in the optimized FRNW-based medium compared to standard HS medium, may significantly lower its production cost. Many agricultural by-products and wastes have been used as a substrate or supplementary substance for $\mathrm{BC}$ production because of their low cost. Thin stillage, a wastewater from rice wine distillery was used as a supplement in culture medium for BC production and the BC yield of $10.38 \mathrm{~g} / \mathrm{L}$ obtained in the medium was 2.5 folds higher than that obtained in the HS medium [9]. Pineapple peel juice was used as a substrate in culture medium for BC biosynthesis and the BC yield of $2.8 \mathrm{~g} / \mathrm{L}$ obtained in the medium was 1.3 folds higher than that obtained in the HS medium [26]. Coffee cherry husk extract was tested as a substrate for $\mathrm{BC}$ production. After 2 weeks of cultivation, the maximum BC yield was obtained at $6.24 \mathrm{~g} / \mathrm{L}$ [27]. Citrus waste was also found an effective nutrient source for BC production [28]. In this study, the cellulose production of $11.76 \pm 0.34 \mathrm{~g} / \mathrm{L}$ in the optimized FRNW-based medium was higher than those observed in the studies mentioned above. Additionally, the cost of FRNW is relatively low and potentially applicable for commercial BC production on a large scale.

\section{Analysis of produced BC paper from different media}

BC paper produced in optimized FRNW-based medium (F-paper) showed higher tensile strength, Young's modulus and Elongation at break than BC paper produced from standard HS medium (H-paper). The properties of the F-paper and H-paper are listed in Table 2. Keshk [29] studied the physical properties of Bacterial Cellulose sheets produced in the standard HS medium and the presence of lignosulfonate (HSL) by Gluconacetobacter xylinus ATCC 10245. The sheets produced in the HSL medium showed the higher tensile strength $(18.28 \mathrm{~N})$ and Young's Modulus $(606.45 \mathrm{MPa})$ than in the standard HS medium (10.0 N and $331.75 \mathrm{MPa}$, respectively). The cellulose fibers in F-paper were tightly combined whereas fibers from H-paper were less tightly combined and more pore occurred. The scanning electron micrographs of both samples are displayed in Figure 6. 

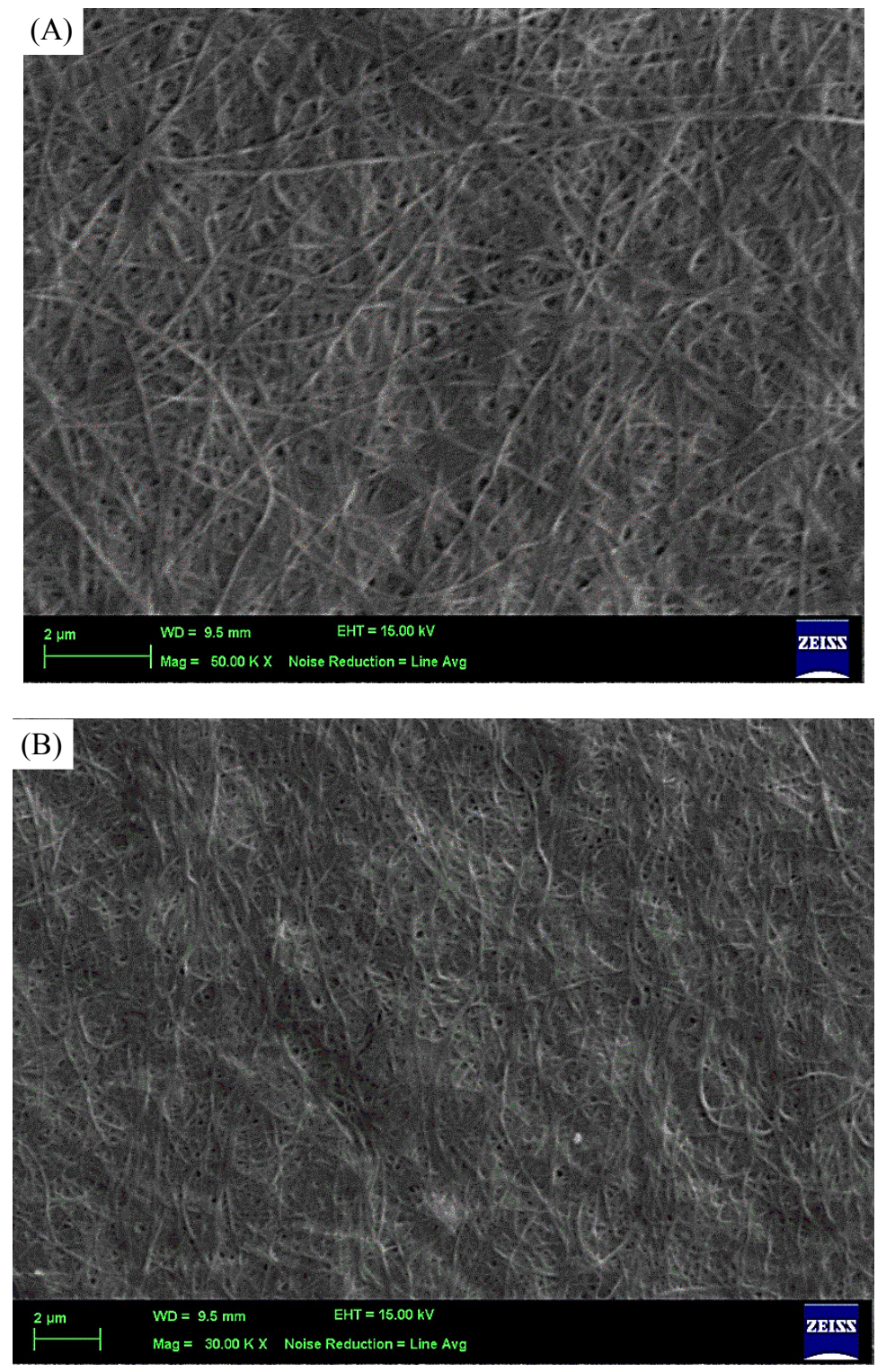

Figure 6 Structure of $\mathrm{BC}$ produced from the standard HS medium (A) and the optimized FRNW-based medium (B) with $30,000 \mathrm{X}$.

Table 1 Comparison of BC yields in optimized medium based on FRNW and standard HS medium.

\begin{tabular}{lc}
\hline \multicolumn{1}{c}{ Medium } & BC yield $(\mathrm{g} / \mathbf{L})$ \\
\hline Optimized FRNW-based medium & $11.76 \pm 0.34$ \\
Standard HS medium & $2.67 \pm 0.65$ \\
\hline
\end{tabular}

The mean of triplicates \pm SD 
http://wjst.wu.ac.th

Table 2 The properties of BC paper produced from the standard HS medium and the optimized FRNWbased medium.

\begin{tabular}{lcc}
\hline \multicolumn{1}{c}{ Mechanical Properties } & H paper & F paper \\
\hline Thickness $(\mu \mathrm{m})$ & $102.30 \pm 4.20$ & $150.25 \pm 5.32$ \\
Tensile strength $\left(\mathrm{N} / \mathrm{m}^{2}\right)$ & $213.23 \pm 3.50$ & $302.15 \pm 2.34$ \\
Young's modulus $\left(\mathrm{N} / \mathrm{m}^{2}\right)$ & $2,468.32 \pm 24.32$ & $2,834.20 \pm 19.02$ \\
Elongation at break $(\%)$ & $8.05 \pm 0.30$ & $12.10 \pm 0.46$
\end{tabular}

The mean of triplicates $\pm \mathrm{SD}$

when $\mathrm{H}$ paper is a paper produced by using obtained $\mathrm{BC}$ from HS medium.

$\mathrm{F}$ paper is a paper produced by using obtained $\mathrm{BC}$ from optimized FRNW-based medium.

\section{Conclusions}

In this study, Bacterial Cellulose from Komagataeibacter sp. PAP1 was produced by using FRNW as a substrate. The appropriated condition for cultivation and $\mathrm{BC}$ production were optimized. The highest yield of BC production was obtained after growing in the optimized FRNW-based medium consisting of $5 \% \mathrm{w} / \mathrm{v}$ mannitol, $0.1 \% \mathrm{w} / \mathrm{v}$ beef extract, $0.5 \% \mathrm{v} / \mathrm{v}$ ethanol, $1 \% \mathrm{v} / \mathrm{v}$ acetic acid, $\mathrm{pH} 7.0$ and incubated at $30{ }^{\circ} \mathrm{C}$ for 10 days. The BC yield was $11.76 \pm 0.34 \mathrm{~g} / \mathrm{L}$ and was 4.4 folds higher than $\mathrm{BC}$ yield in standard HS medium. The obtained results demonstrated that FRNW can be used as raw material for BC production to reduce the production cost and environmental pollution. The bio-cellulose paper using obtained $\mathrm{BC}$ from an optimized FRNW-based medium had a great mechanical strength than those produced in standard HS medium.

\section{Acknowledgements}

This research was financially supported by National Research Council of Thailand and King Mongkut's Institute of Technology Ladkrabang, Thailand.

\section{References}

[1] Y Yamada, P Yukphan, HT Lan Vu, Y Muramatsu, D Ochaikul, S Tanasupawat and Y Nakagawa. Description of Komagataeibacter gen. nov., with proposals of new combinations (Acetobacteraceae). J. Gen. Appl. Microbiol. 2012; 58, 397-404.

[2] A Cavka, X Guo, SJ Tang, S Winestrand, LJ Jönsson and F Hong. Production of bacterial cellulose and enzyme from waste fiber sludge. Biotechnol. Biofuels 2013; 6, 25.

[3] E Tsouko, C Kourmentza, D Ladakis, N Kopsahelis, I Mandala, S Papanikolaou, F Paloukis, V Alves and A Koutinas. Bacterial cellulose production from industrial waste and by-product streams. Int. J. Mol. Sci. 2015; 16, 14832-49.

[4] PR Chawla, IB Bajaj, SA Survase and RS Singhal. Microbial cellulose: Fermentative production and applications. Food Technol. Biotechnol. 2009; 47, 107-27.

[5] AH Basta and H El-Saied. Performance of improved bacterial cellulose application in the production of functional paper. J. Appl. Microbiol. 2009; 107, 2098-107.

[6] WK Czaja, DJ Young, M Kawezki and JR Brown. The future prospects of microbial cellulose in biomedical applications. Biomacromolecules 2007; 8, 1-12. 
http://wjst.wu.ac.th

[7] J Shah and RM Brown. Towards electronic paper displays made from microbial cellulose. Appl. Microbiol. Biotechnol. 2005; 66, 352-5.

[8] P Carreira, JAS Mendes, E Trovatti, LS Serafim, CSR Freive, AJD Silvestre and CP Neto. Utilization of residues from agro-forest industries in the production of high value bacterial cellulose. Bioresour. Technol. 2011; 102, 7354-60.

[9] JM Wu and RH Liu. Thin stillage supplementation greatly enhances bacterial cellulose production by Gluconacetobacter xylinus. Carbohydr. Polym. 2012; 90, 116-21.

[10] FP Gomes, NHCS Silva, E Trovatti, SL Serafim, MF Duarte, AJD Silvestre, CP Neto and CSR Freire. Production of bacterial cellulose by Gluconacetobacter sacchari using dry olive mill residue. Biomass. Bioenerg. 2013; 55, 205-11.

[11] D Lin, P Lopez-Sanchez, R Li and Z Li. Production of bacterial cellulose by Gluconacetobacter hansenii CGMCC 3917 using only waste beer yeast as nutrient source. Bioresour. Technol. 2014; 151, 113-9.

[12] C Huang, HJ Guo, L Xiong, B Wang, SL Shi and XF Chen. Using wastewater after lipid fermentation as substrate for bacterial cellulose production by Gluconacetobacter xylinum. Carbohydr. Polym. 2016; 131, 198-202.

[13] S Siripattanakul-Ratpukdi. Ethanol production potential from fermented rice noodle wastewater treatment using entrapped yeast cell sequencing batch reactor. Appl. Water Sci. 2012; 2, 47-53.

[14] A Suwanposri, Y Yamada, P Yukaphan and D Ochaikul, D. Identification and biocellulose production of Gluconacetobacter strains isolated from tropical fruits in Thailand. Maejo Int. J. Sci. Technol. 2013; 7, 70-82.

[15] D Mikkelsen, BM Flanagen, GA Dykes and MJ Gidley. Influence of different carbon sources on bacterial cellulose production by Gluconacetobacter xylinus strain ATCC 53524. J. Appl. Microbiol. 2009; 107, 576-83.

[16] JD Fontana, CG Joerke, M Baron, M Maraschin, AG Ferreira, I Torriani, AM Souza, MB Soares, MA Fontana and MF Guimaraes. Acetobacter cellulosic biofilms search for new modulators of cellulogenesis and native membrane treatments. Appl. Biotechnol. 1997; 6, 327-38.

[17] F Jahan, V Kumar, G Rawat and RK Saxena. Production of microbial cellulose by a bacterium isolated from fruit. Appl. Biochem. Biotechnol. 2012; 167, 1157-71.

[18] RE Buchanan and NE Gibbons. Bergey's Manual of Determinative Bacteriology. $8^{\text {th }}$ ed. Williams and Wilkins, Baltimore, 1974.

[19] KV Ramana, A Tomar and L Singh. Effect of various carbon and nitrogen sources on cellulose synthesis by Acetobacter xylinum. World J. Microbiol. Biotechnol. 2000; 16, 245-8.

[20] VT Nguyen, B Flanagan, MJ Gidley and GA Dykes. Characterization of cellulose production by a Gluconacetobacter xylinus strain from Kombucha. Curr. Microbiol. 2008; 57, 449-53.

[21] GZ Pourramezan, AM Roayaei and QR Qezelbash. Optimization of culture conditions for bacterial cellulose production by Acetobacter sp. 4B-2. Biotechnol. J. 2009; 8, 150-4.

[22] SY Kim, JN Kim, YJ Wee, DH Park and HW Ryu. Production of bacterial cellulose by Gluconacetobacter sp. RKY 5 isolated from persimmon vinegar. Appl. Biochem. Biotechnol. 2006; 131, 705-15.

[23] BS Hungund and SG Gupta. Improved production of bacterial cellulose from Gluconacetobacter persimmonis GH-2. J. Microb. Biochem. Technol. 2010; 2, 127-33.

[24] HJ Son, HG Kim, KK Kim, HS Kim, YG Kim and SJ Lee. Increased production of bacterial cellulose by Acetobacter sp. V6 in synthetic media under shaking culture conditiond. Biosour. Technol. 2003; 86, 215-9.

[25] M Gama, P Gatenolm and D Klemm. Bacterial Nanocellulose, A Sophisticated Multifunctional Material. CRC Press, Florida, 2013.

[26] C Castro, R Zuluaga, JL Putaux, G Caro, I Mondragon and P Gañán. Structural characterization of bacterial cellulose produced by Gluconacetobacter swingsii sp. from Colombian agroindustrial wastes. Carbohydr. Polym. 2011; 84, 96-102. 
http://wjst.wu.ac.th

[27] MU Rani, NK Rastogi and KAA Appaiah. Statistical optimization of medium composition for bacterial cellulose production by Gluconacetobacter hansenii UAC09 using coffee cherry husk extract-an agro-industry waste. J. Microbiol. Biotechnol. 2011; 21, 739-45.

[28] Y Yang, J Jia, J Xing, J Chen and S Lu. Isolation and characteristics analysis of a novel high bacterial cellulose producing strain Gluconacetobacter intermedius CIs26. Carbohydr. Polym. 2013; 92, 2012-17.

[29] S Keshk, S. Physical properties of bacterial cellulose sheets produced in presence of lignosulfonate. Enzyme. Microb. Technol. 2006; 40, 9-12. 